\title{
Risk behaviors for eating disorder: factors associated in adolescent students
}

\author{
Comportamentos de risco para transtorno alimentar: fatores associados em \\ adolescentes escolares
}

Leonardo de Sousa Fortes, ${ }^{1}$ Flávia Marcele Cipriani, ${ }^{2}$ Maria Elisa Caputo Ferreira ${ }^{3}$

\begin{abstract}
Introduction: Evidence shows that the prevalence of risk behaviors for eating disorders (RBED) among young people has increased in recent years. Body dissatisfaction, excessive exercise, body composition, economic status, and ethnicity may be risk factors for RBED.

Objective: To evaluate the association of body dissatisfaction, psychological commitment to exercise, body fat, nutritional status, economic class, and ethnicity with RBED in adolescents.

Method: This study included 562 boys and girls aged 10 to 15 years. We used the Eating Attitudes Test (EAT-26) to assess RBED. The Body Shape Questionnaire (BSQ) and the Commitment to Exercise Scale (CES) were used to measure body dissatisfaction and commitment to exercise, respectively. Skin fold thickness was measured to classify body fat according to sex. Weight and height were measured to calculate the body mass index (BMI) and classify participants according to nutritional status. The economic class was recorded according to the Brazilian Economic Classification Criterion. A questionnaire was used to record ethnicity, age and sex. Binary logistic regression was used to determine associations between variables. Results: The results showed an association of RBED with body dissatisfaction, CES scores, and economic class among girls ( $p<0.05)$. Among boys, body dissatisfaction, body fat, and nutritional status were associated with RBED ( $p<0.05)$.

Conclusion: Even though body dissatisfaction had the highest odds ratio,
\end{abstract} other variables were also associated with RBED.

Keywords: Eating behavior, adolescents, body image.
Resumo

Introdução: Evidências demonstram que a prevalência de comportamentos de risco para condutas de alimentação inapropriada (CAI) entre jovens tem aumentado nos últimos anos. Tem sido proposto que a insatisfação corporal, a prática excessiva de exercício físico, a composição corporal, o nível econômico e a origem étnica podem ser fatores de risco para CAI.

Objetivo: Avaliar a associação de insatisfação corporal, grau de comprometimento psicológico ao exercício (GCPE), adiposidade corporal, estado nutricional, nível econômico e etnia com CAI em adolescentes.

Método: Participaram do estudo 562 jovens, de ambos os sexos, com idades entre 10 e 15 anos. Utilizou-se o Eating Attitudes Test (EAT-26) para avaliar CAI. O Body Shape Questionnaire (BSQ) e a Commitment Exercise Scale (CES) foram utilizadas para mensurar insatisfação corporal e GCPE, respectivamente. Aferiram-se dobras cutâneas para classificar a adiposidade corporal segundo o sexo. Peso e estatura foram aferidos para calcular o índice de massa corporal (IMC) e determinar o estado nutricional. Nível econômico foi avaliado de acordo com o Critério de Classificação Econômica Brasil. Aplicou-se questionário para avaliar etnia, idade e sexo. Conduziu-se regressão logística binária para determinar associações entre as variáveis da pesquisa.

Resultados: Houve associação de CAI com insatisfação corporal, GCPE e nível econômico no sexo feminino $(p<0,05)$. Entre os meninos, insatisfação corporal, adiposidade corporal e estado nutricional estiveram associados a CAI $(p<0,05)$.

Conclusão: Embora a insatisfação corporal tenha apresentado os maiores valores de odds ratio, outras variáveis também estiveram associadas a CAI. Descritores: Comportamento alimentar, adolescentes, imagem corporal.

${ }^{1}$ MSc in Physical Education, Universidade Federal de Juiz de Fora (UFJF), Juiz de Fora, MG, Brazil. Professor, Núcleo de Educação Física e Ciências do Esporte, Universidade Federal de Pernambuco (UFPE), Vitória de Santo Antão, PE, Brazil. The Body and Human Diversity Research Group, Conselho Nacional de Desenvolvimento Científico e Tecnológico (CNPq). ${ }^{2}$ Lato sensu degree in Pedagogical Inspection and Coordination, Pontifícia Universidade Católica de Minas Gerais (PUC-MG), Juiz de Fora, MG, Brazil. Laboratory of Studies of the Body, UFJF, Juiz de Fora, MG, Brazil. The Body and Human Diversity Research Group, CNPq. ${ }^{3}$ PhD in Education, Universidade de São Paulo (USP), São Paulo, SP, Brazil. Professor, Department of Physical Education Fundamentals, UFJF, Juiz de Fora, MG, Brazil. Laboratory of Studies of the Body, UFJF, Juiz de Fora, MG, Brazil. The Body and Human Diversity Research Group, CNPq. Financial support: Conselho Nacional de Desenvolvimento Científico e Tecnológico (CNPq).

Submitted Oct 16 2012, accepted for publication Oct 07 2013. No conflicts of interest declared concerning the publication of this article.

Suggested citation: Fortes LS, Cipriani FM, Ferreira MEC. Risk behaviors for eating disorder: factors associated in adolescent students. Trends Psychiatry Psychother. 2013;35(4):279-286. http://dx.doi.org/10.1590/2237-6089-2012-0055 


\section{Introduction}

Adolescence is the period between ages 10 to 19 years, ${ }^{1}$ although other definitions may also be found. During this period, young people go through social, psychological, and morphological changes, ${ }^{2}$ which, however, vary in time, duration, and intensity between individuals. Girls, for example, usually reach growth peak at 12 years, whereas boys reach this maturational landmark at around 14 years of age. ${ }^{3}$

Students may be more vulnerable to the modulation of their feelings and behaviors associated with their own body during this phase. ${ }^{4-6}$ This may be explained by the possible negative influences from parents and friends and the pressure to lose weight and invest in their physical appearance, which may predispose them to the development of risk behaviors for eating disorders. ${ }^{7,8}$

Risk behaviors for eating disorders are harmful health habits that developed as an attempt to lose or control body weight. ${ }^{9,10}$ Some of them are: self-induced vomiting, eating restraints, eating compulsions, and use of drugs to lose weight (diuretics, laxatives, and diet pills). ${ }^{11}$ Because of their characteristics, these behaviors are part of the diagnostic criteria for eating disorders, such as anorexia nervosa and bulimia nervosa. ${ }^{12}$

Studies in the literature list some risk factors of behaviors that may lead to eating disorders in adolescents, such as: a) body dissatisfaction - a profound dislike of one's own body,11,13-18; b) extenuating practice of physical activities ${ }^{19} ;$ c) inadequate nutritional status ${ }^{20}$; d) elevated body fat $^{6}$; e) ethnicity (white) ${ }^{10}$; and f) elevated socioeconomic status. ${ }^{7,21}$

Even though there is scientific evidence that the factors listed above are associated with risk behaviors for eating disorders among adolescents, some controversial issues remains unsolved. For example, some studies found that nutritional status, ${ }^{16,20}$ ethnicity, ${ }^{9}$ and economic status ${ }^{21}$ were associated with risk behaviors for eating disorders. Therefore, these factors should be better investigated. Additionally, to our knowledge, no studies in Brazil have investigated the association between excessive physical exercise and risk behaviors for eating disorders, and most studies have included only female samples. Therefore, affective and behavioral variables have not been evaluated among boys as frequently as among girls.

This study evaluated the association of body dissatisfaction, psychological commitment to exercise, body fat, nutritional status, economic status, and ethnicity with risk behaviors for eating disorders. For that purpose, some hypotheses were made, both for boys and girls, taking into consideration data in the literature..$^{4-7,20,21}$ The risk of developing risk behaviors for eating disorders was calculated for: 1) adolescents dissatisfied with their body image; 2) adolescents with a high degree of psychological commitment to exercise; 3) adolescents with an inadequate body shape; 4) adolescents of higher economic classes; and 5) and, finally, white adolescents.

\section{Material and methods}

This cross-sectional study, conducted in 2011, was approved by the Research Ethics Committee for Studies with Human Beings of Universidade Federal de Juiz de Fora under no. 2282.022.2011 and according to specialist opinion no. 022/11, according to Resolution 196/96 of the Brazilian National Health Council.

\section{Participants}

This study included adolescent boys and girls aged 10 to 15 years who attended elementary schools in the city of Juiz de Fora, Brazil. According to the 2011 Brazilian School Census, this population included about 60,000 adolescents in the city. The sample was calculated using the method described by Miranda et al. ${ }^{4}$ and Field. ${ }^{22}$ An absolute accuracy of \pm 2 points was adopted for the reference response variable, the Eating Attitudes Test (EAT-26). ${ }^{15}$ The worst scenario at a level of significance of $1 \%$ was the greatest score variability for girls $( \pm 12.9$ points). ${ }^{6}$ The minimum sample size was 276 after correction for finite populations. A total of 595 students were included in the study, but 33 did not complete the questionnaires or did not participate in anthropometric measurements, and the final sample comprised 562 adolescents (299 girls and 263 boys). Sample power was calculated according to the recommendations made by Field, ${ }^{22}$ and the result was 0.9 . Therefore, statistical significance, as well as effect size in this study, had a $90 \%$ chance of being reproduced in other studies with a representative sample of the same population.

Selections were made at random using a simple number draw in two stages. First, the school in each sociodemographic region was chosen, and, after that, the adolescents in each of these units. Schools were selected according to the list provided by the statistics service of the Education Department of the State of Minas Gerais, Brazil. The principals of 11 schools (five private and six public schools) were invited to participate in the study after receiving information about the study objectives and procedures. However, only eight (four private and four public schools) agreed to allow their students to participate in data collection. The final study sample was recruited at eight different collection sites (schools) and comprised adolescents present on collection days. 


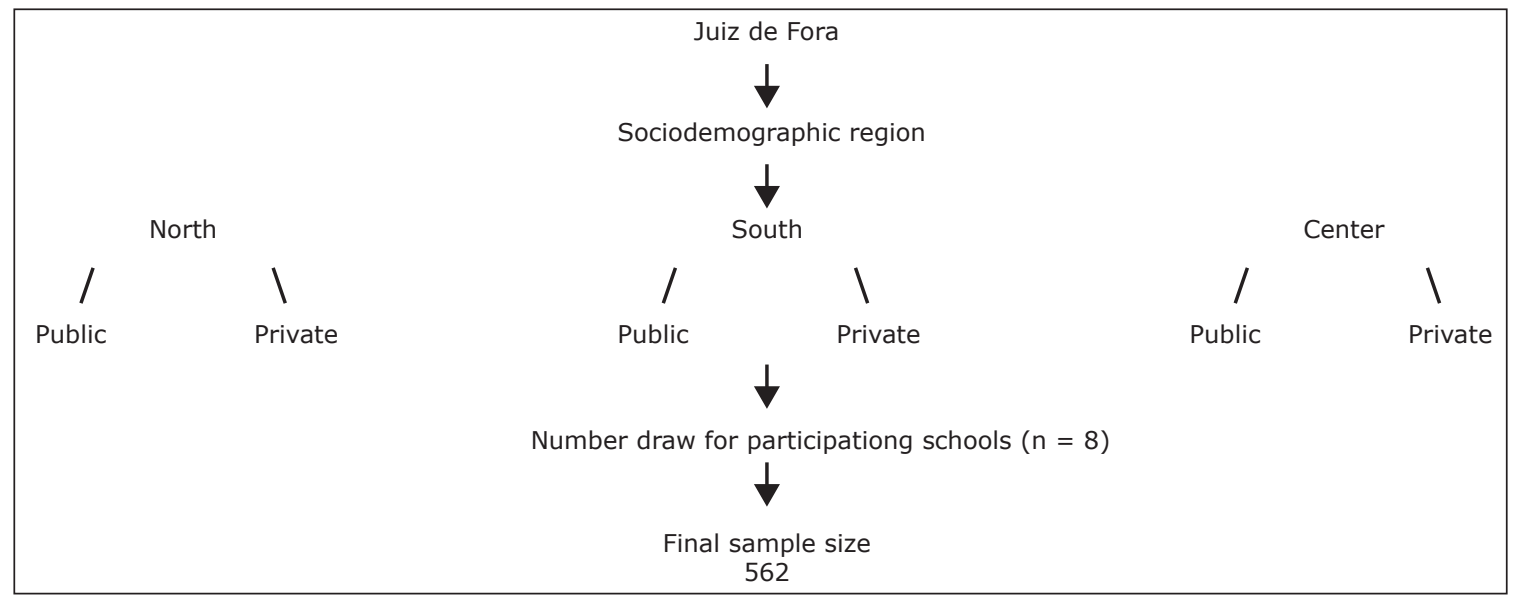

Figure 1 - Sample selection

Inclusion criteria were: 1 ) to be regularly registered in an elementary or secondary school in Juiz de Fora; 2 ) to be available to answer questionnaires; 3 ) to be available to participate in anthropometric measurements; and 4 ) to be 10 to 15 years old. In addition, parents or guardians should sign an informed consent term and authorize participation.

\section{Instruments}

The EAT-2623,24 was used to assess risk behaviors for eating disorders. It is a self-report Likert-like instrument with 26 questions, and answers range from $0=$ never to 3 = always, except for question 25, for which the score is reversed ( 0 = always, frequently, sometimes; $1=a$ few times; 2 =almost never; 3 = never). If the score was $\geq$ 20 , individuals were at risk of developing eating disorders $\left(\mathrm{EAT}_{+}\right)$. The EAT-26 questions evaluate diet, concern with physical appearance and food consumption, symptoms of bulimia, environmental and social pressure to eat, as well as oral control. In this study, two versions of the EAT26 questionnaire were used, the one validated for use with Brazilian adolescent girls ${ }^{23}$; and the one validated for use with Brazilian adolescent boys. ${ }^{24}$ Their internal consistency was 0.82 and 0.88 . Cronbach's alpha was 0.89 for girls and 0.86 for girls.

The Body Shape Questionnaire (BSQ) ${ }^{25}$ was used to evaluate body dissatisfaction. This tool is made up of 34 Likert-like questions, in which answers range from $1=$ never to 6 = always. It is used to evaluate the frequency of concerns about weight and physical appearance. BSQ classifies individuals into four groups according to the total score of body dissatisfaction: $<80=$ free of body dissatisfaction; 80-110 = mild body dissatisfaction; $110-140=$ moderate body dissatisfaction; $\geq 140=$ severe body dissatisfaction. This questionnaire has been validated for a Brazilian population of adolescents by Conti et al. ${ }^{25}$ Internal consistency was 0.96 for both sexes and the coefficient of correlation between the testretest scores was significant, ranging from 0.89 to 0.91 for boys and girls. For our sample, Cronbach's alpha was 0.92 to 0.90 for boys and girls.

The Commitment to Exercise Scale (CES) ${ }^{19}$ was used to determine the degree of psychological commitment to exercise. This instrument has been translated, adapted and validated for Portuguese by Teixeira et al., ${ }^{19}$ and Cronbach's alpha was 0.79 . The CES evaluates the degree at which the sensations of well-being are modulated by physical exercises, maintenance of exercise in face of adverse situations and the degree of interference of physical activity in an individual's social commitments. It is a visual analog scale for eight questions, ranging from 0 to $155 \mathrm{~mm}$ and, therefore, the maximal total score is $1,240 \mathrm{~mm}$. Scores greater than 640 indicate that the individual has a high degree of psychological commitment to exercise $\left(\mathrm{CES}_{+}\right) \cdot{ }^{19}$ Internal consistency was calculated for our sample, and Cronbach's alpha was 0.67 and 0.70 for girls and boys.

\section{Other variables}

\section{Body fat}

Body fat was defined as body fat percentage (\%BF), estimated using an indirect method: triceps and subscapular skin folds were measured to the nearest $0.1 \mathrm{~mm}$ using a skinfold caliper (Lange $\left.{ }^{\circledR}\right)$. Estimates were calculated according to the method described by Slaughter et al. ${ }^{26}$ The data for these variables were collected according to the standards defined by the International Society for the Advancement of Kinanthropometry (ISAK). ${ }^{27}$ Measurements were made in rotation and collected three times, and the mean value was recorded. This variable was classified according to the cut-off points defined by Lohman, ${ }^{28}$ 
which takes into consideration sex. Results for girls were: $<11 \%=$ very low; $>12 \%$ and $<15 \%=$ low; $>16 \%$ and $<25 \%=$ normal; $>26 \%$ and $<30 \%=$ moderately high; $>31 \%$ and $<35 \%=$ high; $>35 \%=$ very high. For boys, results were: $<6 \%=$ very low; $>$ $7 \%$ and $<12 \%=$ low $;>13 \%$ and $<18 \%=$ normal; $>19 \%$ and $<25 \%=$ moderately high; $>26 \%$ and $<$ $32 \%=$ high; and $>32 \%=$ very high.

\section{Nutritional status}

Body mass index (BMI), calculated as body mass ( $\mathrm{kg}$ ) divided by squared height $\left(\mathrm{m}^{2}\right)$, was used as the index of nutritional status. Body mass was measured to the nearest $100 \mathrm{~g}$ using a portable digital scale (Tanita) measuring up to $200 \mathrm{~kg}$. A portable stadiometer measuring to the nearest $0.1 \mathrm{~cm}$ and to a maximum height of $2.20 \mathrm{~m}$ (Welmy) was used to measure the height of the adolescents. BMI was classified using the criteria issued by the World Health Organization (WHO) ${ }^{1}$ : low weight, normal weight, overweight and obesity according to percentiles (5th, 85th and 95th) and age.

\section{Economic status}

Economic status was determined according to the Brazilian Economic Classification Criterion (Critério de Classificação Econômica Brasil, CCEB), ${ }^{29}$ developed by the Brazilian Association of Market Research Companies (Associação Brasileira de Empresas de Pesquisa, ABEP). This criterion is primarily based on an estimate of the buying power of urban individuals and families and does not attempt to classify populations according to social classes. This instrument evaluates the number of comfort items (car, refrigerator, television, etc.) purchased, as well as the level of education of the head of the family. Economic classes are defined according to the following cut-off points: $A 1=30-34 ; A 2=25-29 ; B 1=21-24 ; B 2$ $=17-20 ; C=11-16 ; \mathrm{D}=6-10 ; \mathrm{E}-0-5$ points.

\section{Ethnicity}

Ethnicity was determined according to self-report. Adolescent could choose one of three options: white, black, or Asian. This classification was partially based on studies conducted by Pernick et al. ${ }^{13}$ and Sampei et al. ${ }^{10}$

\section{Procedures}

Before the beginning of the study, school principals were contacted to explain the study purposes and procedures. After authorization was granted, the authors contacted students in each class to give them information about data collection and hand out the informed consent term, which should be returned one week later after their parents or guardians had signed it.

After this first phase, data were collected, from March to June 2011, at two time points. First, in the classroom, after the informed consent term signed by parents or guardians was returned, the students individually answered the questionnaires, which had a heading where they could enter their name (optional), sex, age and ethnicity. When the questionnaires were returned (second time point), the student was sent to a room made available by the school for the measurement of skin folds, weight and height. For measurements, the adolescent should be wearing the physical education uniform and should be barefoot.

\section{Statistical analysis}

Multivariate statistical procedures were used to evaluate results. The SPSS 17.0 was used for statistical analysis, and the level of significance was set at $5 \%$. Central tendency measures (mean and standard deviation) and absolute and relative frequencies were used to describe study variables. The Mann Whitney test was used to compare some of the variables (EAT-26, BSQ, CES, \%BF, BMI, CCEB, and age) according to sex. Binary logistic regression was used to evaluate the association between independent variables (body dissatisfaction, psychological commitment to exercise, \%BF, nutritional level, economic class and ethnicity) and risk behaviors for eating disorders. For that, the classifications of body dissatisfaction according to BSQ were all grouped as dissatisfied; the very low and low body fat classifications were grouped into low \%BF, and the moderately high, high and very high results, into high \%BF. Moreover, the overweight and obesity subgroups were classified together as overweight; economic status (CCEB) was recorded as $A$ ( $A 1$ and $A 2), B(B 1$ and $B 2)$ and $C(C, D$ and $E$ ) classes.

\section{Results}

This study included 562 individuals (263 boys and 299 girls). Participants studied in eight elementary schools (four private and four public schools) in Juiz de Fora. Central tendency measures (mean and standard deviation) of all study variables (EAT-26, BSB, CES, $\% B F, B M I, C C E B$ and age) and frequency distribution of ethnicity are shown in Table 1.

In the analysis of odds ratios of risk behaviors for eating disorders among girls, logistic regression revealed an association with body dissatisfaction $\left(\chi^{2}=51.78\right.$; Wald $=35.27 ; \mathrm{p}=0.001)$, degree of psychological commitment to exercise $\left(\chi^{2}=38.55 ;\right.$ Wald $\left.=28.09 ; p=0.002\right)$ and economic level $\left(\chi^{2}=11.55\right.$; Wald $=6.43 ; p=0.04$ ) (Table 2 ). This statistical test also indicated that girls that were dissatisfied with their weight and physical appearance, had an elevated degree of psychological commitment to exercise and belonged to economic classes A and B had $677 \%$ and $834 \%$ greater chances of developing risk behaviors for eating disorders $(p<0.05)$. 
Table 1 - Description (mean, standard deviation or frequency) of the study variables

\begin{tabular}{|c|c|c|}
\hline \multirow{2}{*}{ Variable } & Girls (n = 299) & Boys $(n=263)$ \\
\hline & Mean (standard deviation) & Mean (standard deviation) \\
\hline EAT-26* & $15.08 \pm 11.18$ & $11.49 \pm 11.46$ \\
\hline BSQ* & $79.96 \pm 35.29$ & $62.81 \pm 28.33$ \\
\hline CES & $498.18 \pm 215.53$ & $548.66 \pm 218.49$ \\
\hline$\% \mathrm{BF}^{*}$ & $25.66 \pm 7.27$ & $21.74 \pm 10.26$ \\
\hline BMI & $19.77 \pm 3.66$ & $19.97 \pm 3.51$ \\
\hline CCEB & $18.93 \pm 4.89$ & $19.06 \pm 4.59$ \\
\hline \multirow[t]{2}{*}{ Age } & $12.73 \pm 1.59$ & $12.65 \pm 1.69$ \\
\hline & n (\%) & n (\%) \\
\hline \multicolumn{3}{|l|}{ Ethnicity } \\
\hline White & $167(55.8 \%)$ & $150(57.0 \%)$ \\
\hline Black & $81(27.1 \%)$ & $68(25.9 \%)$ \\
\hline Asian & $51(17.1 \%)$ & $45(17.1 \%)$ \\
\hline \multicolumn{3}{|c|}{ Nutritional status } \\
\hline Low weight & $64(21.4 \%)$ & $31(11.8 \%)$ \\
\hline Normal weight & $143(47.8 \%)$ & $145(55.1 \%)$ \\
\hline Overweight & $92(30.8 \%)$ & $87(33.1 \%)$ \\
\hline \multicolumn{3}{|l|}{ Economic class } \\
\hline A & $56(18.7 \%)$ & $43(16.3 \%)$ \\
\hline B & $162(54.2 \%)$ & $112(42.6 \%)$ \\
\hline C & $81(27.1 \%)$ & $108(41.1 \%)$ \\
\hline
\end{tabular}

\%BF = percentage of body fat; CCEB = Critério de Classificação Econômica Brasil (Brazilian Economic Class Classification); BMI = body mass index; BSQ = Body Shape Questionnaire; CES = Commitment to Exercise Scale; EAT-26 = Eating Attitudes Test.

$* \mathrm{p}<0.05$ between sexes, Mann Whitney test.

Among boys, body dissatisfaction $\left(\chi^{2}=22.70\right.$; Wald $=11.96 ; \mathrm{p}=0.001)$, \%BF $\left(\chi^{2}=4.63 ;\right.$ Wald $=3.56$; $\mathrm{p}=0.04)$ and nutritional status $\left(\chi^{2}=14.21\right.$; Wald $=$ $10.83 ; p=0.03$ ) were associated with risk behaviors for eating disorders, as seen in Table 2. Therefore, results indicated that adolescents dissatisfied with their body, with low \%BF and low weight (nutritional status) had an increased risk (233\% greater chances) of developing risk behaviors for eating disorders $(p<0.05)$. In a similar way, body dissatisfaction, high \%BF and overweight (nutritional status) indicated vulnerability and 934\% greater chances of adopting eating habits that are harmful to the health $(p<0.05)$.

\section{Discussion}

This study evaluated the association of body dissatisfaction, psychological commitment to exercise, body fat, nutritional status, economic class and ethnicity with risk behaviors for eating disorders.

For girls, body dissatisfaction was the variable that indicated greatest chance of developing risk behaviors for eating disorders. These results are in agreement with some factors reported in other studies. ${ }^{7,14,21}$ Body dissatisfaction seemed to be the main variable to reflect chances of developing risk behaviors for eating disorders among girls. 5,6,18

This study also found that girls with CES scores above $640\left(\mathrm{CES}_{+}\right)$, i.e., those with a high degree of psychological commitment to exercise, had a $214 \%$ greater chance of developing risk behaviors for eating disorders than adolescents with scores below 640. We did not find any other studies with a similar analysis for comparisons. Other authors, however, found that individuals with risk behaviors for eating disorders usually practice exercises excessively. ${ }^{30}$

Therefore, girls that practice exercises exaggeratedly seem to hold that habit in an attempt to reduce depreciative feelings about their own body. ${ }^{12,30}$ However, this phenomenon seems to be a cascade event, i.e., girls dissatisfied with their body seek physical exercises as they aim to remodel their bodies, ${ }^{4}$ but, in doing so, they may increase their chances of developing eating habits that are deleterious to health when their commitment to exercise is exaggerated. ${ }^{30}$ Teixeira et al. ${ }^{12}$ have discussed a possible explanation for this fact and found that girls with risk behaviors for eating disorders tend to maximize body weight loss by engaging in extenuating physical activity. 
Table 2 - Odds ratio of risk behaviors for eating disorders (reference category: EAT < 20) among girls and boys according to body dissatisfaction, degree of psychological commitment to exercise, percentage of body fat, nutritional status, economic class and ethnicity

\begin{tabular}{|c|c|c|}
\hline Variable & OR* & $95 \% \mathrm{CI}$ \\
\hline \multicolumn{3}{|l|}{ Girls } \\
\hline BSQ* & 1.00 & - \\
\hline Satisfied $(n=194)$ & 19.44 & $7.66-21.88$ \\
\hline \multicolumn{3}{|l|}{ Dissatisfied $(n=105)$} \\
\hline CES* & 1.00 & - \\
\hline Negative $(n=210)$ & 2.14 & $2.05-5.41$ \\
\hline \multicolumn{3}{|l|}{ Positive $\left(\mathrm{CES}_{+}\right)(\mathrm{n}=89)$} \\
\hline$\% B F$ & 0.67 & $0.08-5.29$ \\
\hline Low $(n=55)$ & 1.00 & - \\
\hline Normal $(n=168)$ & 1.42 & $0.48-4.24$ \\
\hline \multicolumn{3}{|l|}{ High $(n=76)$} \\
\hline NS & 1.13 & $1.05-13.88$ \\
\hline Low weight $(n=64)$ & 1.00 & - \\
\hline Normal weight $(n=143)$ & 2.14 & $0.56-8.13$ \\
\hline \multicolumn{3}{|l|}{ Overweight $(n=92)$} \\
\hline EC* & 1.16 & $1.04-3.10$ \\
\hline$A(n=56)$ & 3.94 & $1.99-5.65$ \\
\hline$B(n=162)$ & 1.00 & - \\
\hline \multicolumn{3}{|l|}{$C(n=81)$} \\
\hline Ethnicity & 0.83 & $0.31-2.22$ \\
\hline White $(n=167)$ & 1.00 & - \\
\hline Black $(n=81)$ & 0.84 & $0.13-5.64$ \\
\hline \multicolumn{3}{|l|}{ Asian $(n=51)$} \\
\hline \multicolumn{3}{|l|}{ Boys } \\
\hline \multicolumn{3}{|l|}{ BSQ* } \\
\hline Satisfied $(n=198)$ & 1.00 & - \\
\hline Dissatisfied $(n=65)$ & 7.97 & $3.56-9.81$ \\
\hline \multicolumn{3}{|l|}{ CES } \\
\hline Negative $(n=177)$ & 1.00 & - \\
\hline Positive $\left(\mathrm{CES}_{+}\right)(\mathrm{n}=86)$ & 0.94 & $0.32-2.75$ \\
\hline \multicolumn{3}{|l|}{$\% \mathrm{BF}^{*}$} \\
\hline Low $(n=38)$ & 4.16 & $3.56-8.74$ \\
\hline Normal $(n=149)$ & 1.00 & - \\
\hline High $(n=76)$ & 5.77 & $3.66-20.26$ \\
\hline \multicolumn{3}{|l|}{ NS* } \\
\hline Low weight $(n=31)$ & 6.63 & $3.41-10.71$ \\
\hline Normal weight $(n=145)$ & 1.00 & - \\
\hline Overweight $(n=87)$ & 1.27 & $1.06-9.92$ \\
\hline \multicolumn{3}{|l|}{ EC* } \\
\hline$A(n=43)$ & 1.15 & $0.36-3.68$ \\
\hline$B(n=112)$ & 0.69 & $0.09-5.06$ \\
\hline$C(n=108)$ & 1.00 & - \\
\hline
\end{tabular}

(cont.) (cont.)

\begin{tabular}{lll}
\hline Ethnicity & & \\
White $(n=150)$ & 1.11 & $0.31-3.97$ \\
Black $(n=68)$ & 1.00 & - \\
Asian $(n=45)$ & 0.10 & $0.01-4.25$ \\
\hline
\end{tabular}

$\% \mathrm{BF}=$ percentage of body fat; $95 \% \mathrm{CI}=95 \%$ confidence interval; $\mathrm{BSQ}=$ Body Shape Questionnaire; CES = Commitment to Exercise Scale; EC = economic class; NS = nutritional status; OR = odds ratio adjusted to all variables. $* p<0.05$.

Our study did not find any associations of body fat or nutritional status with risk behaviors for eating disorders among girls. However, other studies found that girls with high percentages of body fat or overweight and obesity according to BMI had higher chances of developing risk behaviors for eating disorders. ${ }^{14,21}$ Even though no associations were found, high percentages of body fat may lead to higher chances of developing risk behaviors for eating disorders among girls. ${ }^{5,6}$

Dunker et al. ${ }^{21}$ found that risk behaviors for eating disorders are more frequent in the highest economic classes, which differs from findings in our study. In contrast, some authors claim that this tendency is more common in large capital cities or regions with a high development index (HDI) and may not apply to smaller cities, ${ }^{14}$ such as Juiz de Fora. Finally, ethnicity was not associated with the EAT-26 results in the binary logistic regression model. In contrast, Sampei et al. ${ }^{10}$ found that young Caucasian (white) girls had $243 \%$ greater chances of developing risk behaviors for eating disorders. Therefore, ethnicity remains an imprecise factor in the analysis of development of risk behaviors for eating disorders.

Body dissatisfaction among boys was also the variable that led to greater chances of developing risk behaviors for eating disorders. Studies about the possibility of association of risk behavior for eating disorders and risk factors for that outcome among boys are rare, which makes it difficult to compare results between studies. According to some authors, body dissatisfaction among boys, as well as among girls, seems to be the main variable in leading to risk behaviors for eating disorders. ${ }^{4,20}$

The degree of psychological commitment to exercise

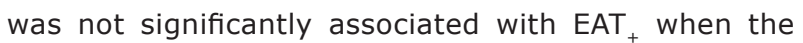
EAT-26 was included in the logistic regression model. Risk behaviors for eating disorders among boys seem to be independent from excessive physical activity. ${ }^{30}$ A possible explanation for that finding is the fact that excessive physical exercise among boys is more specifically linked to the gain of muscle mass, and not to eating restraints or bulimia symptoms. ${ }^{12}$

In contrast, body fat was associated with risk behaviors for eating disorders among boys. According to 
some authors, adolescents with a percentage of body fat below normal usually hold food restraints as an eating habit, whereas adolescents with a high body fat may have symptoms of eating compulsions. ${ }^{14,18}$ As for body fat, nutritional status was also associated with this study outcome among boys. We found greater chances of risk behaviors for eating disorders among individuals with low body weight. These findings are in agreement with the hypotheses raised by Johnson et al., ${ }^{9}$ who found that boys with a low weight usually have a greater tendency to food restraints and a marked concern with their physical appearance, and that they are also susceptible to negative social pressures to food ingestion.

In contrast, economic class and ethnicity were not associated with EAT-26, among boys. Boys tend to have lower chances of developing risk behaviors for eating disorders regardless of economic class or ethnicity. ${ }^{9,13}$ Boys of different economic classes and ethnicities may suffer similar influences towards an ideal body from the media. However, as our study did not investigate the effect of the media, this possibility should be carefully analyzed in future studies.

The results of our study are relevant for Brazilian science, but should be carefully interpreted. Selfapplicable questionnaires were used as study instruments. According to the authors, questionnaires may not reflect the reality of the context evaluated because they are self-report instruments with subjective answers. ${ }^{11}$ In contrast, other authors claim that in studies with large samples, questionnaires are acceptable instruments because they are easy to manage and their operational cost is low. ${ }^{4}$ In addition, ethnicity was evaluated using an instrument developed by the authors, which may be another limitation of this study. However, other studies used the same evaluation method for that variable. ${ }^{9,10,13}$ Finally, its cross-sectional design does not allow for conclusions about causes. Therefore, the degree of intensity and the direction of the associations found between the study outcome and the independent variables could not be evaluated. In fact, this is a limitation of cross-sectional studies, as results are a snapshot of the context evaluated. Despite these limitations, this study may fill part of the gaps in our knowledge, particularly about boys, which may be discussed in future studies.

\section{Conclusion}

Risk behaviors for eating disorders are associated with body dissatisfaction and degree of psychological commitment to exercise among girls, which corroborates the hypotheses raised in this study. However, findings about economic class for girls contradicted our initial hypotheses. In contrast, only body dissatisfaction, body fat and nutritional status were associated with the study outcome among boys. These findings confirm the hypotheses raised in this study.

Future studies should evaluate the associations of physical exercise and personality traits with risk behaviors for eating disorders among boys and girls because of the great diversity of explanatory variables for this outcome. Our findings suggest that multidisciplinary intervention programs should be conducted in both public and private schools in Juiz de Fora to guide students about correct eating behaviors, healthy everyday habits and their relation with their own body, which is constantly changing during adolescence.

\section{References}

1. World Health Organization. Development of a WHO growth reference for school-aged children and adolescents. Bull World Health Organ. 2007; 85:660-7.

2. Siervogel RM, Demerath EW, Schubert C, Remsberg KE, Chumlea WC, Sun S, et al. Puberty and body composition. Horm Res. 2003;60:36-45.

3. Machado DR, Bonfim MR, Costa LT. Pico de velocidade de crescimento como alternativa para classificação maturacional associada ao desempenho motor. Rev Bras Cineantropom Desempenho Hum. 2009;11:14-21.

4. Miranda VP, Conti MA, Bastos R, Ferreira ME. Insatisfação corporal em adolescentes brasileiros de municípios de pequeno porte de Minas Gerais. J Bras Psiquiatr. 2011;60:190-97.

5. Scherer FC, Martins CR, Pelegrini A, Matheus SC, Petroski EL. Imagem corporal em adolescentes: associação com a maturação sexual e sintomas de transtornos alimentares. ] Bras Psiquiatr. 2010;59:198-202.

6. Martins CR, Pelegrini A, Matheus SC, Petroski EL. Insatisfação com a imagem corporal e a relação com estado nutricional, adiposidade corporal e sintomas de anorexia e bulimia em adolescentes. Rev Psiquiatr RS. 2010;32:19-23.

7. do Vale AM, Kerr LR, Bosi ML. Comportamento de risco para transtornos do comportamento alimentar entre adolescentes do sexo feminino de diferentes estratos sociais do Nordeste do Brasil. Cien Saude Colet. 2011;16:121-32.

8. White J, Halliwell E. Examination of a sociocultural model of excessive exercise among male and female adolescents. Body Image. 2010;7:227-33.

9. Johnson C, Crosby R, Engel S, Mitchell J, Powers P, Wittrock D, et al. Gender, ethnicity, self-esteem and disordered eating among college athletes. Eat Behav. 2004;5:147-56.

10. Sampei MA, Singulem DM, Novo NF, Juliano $Y$, Colugnati FA. Atitudes alimentares e imagem corporal em meninas adolescentes de ascendência nipônica e caucasiana em São Paulo (SP). J Pediatr (Rio J). 2009;85:122-28.

11. Schaal K, Tafflet M, Nassif $H$, Thibault V, Pichard C, Alcotte M, et al. Psychological balance in high level athletes: gender-based differences and sport-specific patterns. PLoS One. 2011;6:1-9.

12. Teixeira PC, da Costa RF, Matsudo SM, Cordás TA. A prática de exercícios físicos em pacientes com transtornos alimentares. Rev Psiquiatr Clin. 2009;36:145-52.

13. Pernick $Y$, Nichols JF, Rauh MJ, Kern M, Ji M, Lawson MJ, et al. Disordered eating among a multi-racial/ethinic sample of female high-school athletes. J Adolesc Health. 2006;38:689-95.

14. Alves $E$, Vasconcelos FA, Calvo MC, Neves J. Prevalência de sintomas de anorexia nervosa e insatisfação com a imagem corporal em adolescentes do sexo feminino do Município de Florianópolis, Santa Catarina, Brasil. Cad Saude Publica. 2008;24:503-12.

15. Garner DM, Olmsted MP, Bohr Y, Garfinkel PE. The Eating Attitudes Test: psychometric features and clinical correlates. Psychol Med. 1982;12:871-8.

16. Rivas $T$, Bersabé $R$, Jiménez $M$, Berrocal $C$. The Eating Attitudes Test (EAT-26): reliability and validity in Spanish female samples. Span J Psychol. 2010;13:1044-56. 
17. Silva L, Gomes AR, Martins C. Psychological factors related to eating disordered behaviors: a study with Portuguese athletes. Span J Psychol. 2011;14:323-35.

18. Alvarenga MS, Scagliusi FB, Philippi ST. Comportamento de risco para transtorno alimentar em universitárias brasileiras. Rev Psiquiatr Clin. 2011;38:3-7.

19. Teixeira PC, Hearst N, Matsudo SM, Cordás TA, Conti MA. Adaptação transcultural: tradução e validação de conteúdo da versão brasileira do Commitment Exercise Scale. Rev Psiquiatr Clin. 2011;38:24-8.

20. Pelegrini A, Petroski EL. The association between body dissatisfaction and nutritional status in adolescent. Hum Mov Sci. 2010;11:51-7.

21. Dunker $\mathrm{KL}$, Fernandes $\mathrm{CP}$, Filho $\mathrm{DC}$. Influência do nível socioeconômico sobre comportamentos de risco para transtornos alimentares em adolescentes. J Bras Psiquiatr. 2009;58:156-61.

22. Field A. Descobrindo a estatística usando o SPSS. Porto Alegre: Artmed; 2009

23. Bighetti $F$, Santos $C B$, Santos JE, Ribeiro RP. Tradução e avaliação do Eating Attitudes Test em adolescentes do sexo feminino de Ribeirão Preto, São Paulo. J Bras Psiquiatr. 2004;53:339-46.

24. Fortes LS, Amaral AC, Conti MA, Cordás TA, Ferreira ME. Qualidades psicométricas do Eating Attitudes Test (EAT-26) para a população adolescente masculina brasileira. Psicol Reflex Crit. 2012. No prelo.

25. Conti MA, Cordás TA, Latorre MR. Estudo de validade e confiabilidade da versão brasileira do Body Shape Questionnaire (BSQ) para adolescentes. Rev Bras Saude Mater Infant. 2009;9:331-38.
26. Slaughter $M H$, Lohman TG, Boileau RA, Horswill CA, Stillman RJ, Van Loan MD, et al. Skinfold equations for estimation of body fatness in children and youth. Hum Biol. 1988;60:709-23.

27. The International Society for Advancement of Kinanthropometry (ISAK). National Library of Australia, 2001-2007. www. isakonline. com. Accessed 2013 Jul.

28. Lohman TG. The use of skinfolds to estimate body fatness on children and youth. J Phys Educ Recreat Dance, 1987:58:98-103.

29. Associação Brasileira de Empresas de Pesquisa (ABEP). Critério de classificação econômica Brasil. 2003. http://www.abep.org/ novo/Content.aspx?ContentID=302. Accessed 2009 Jul 10.

30. Modolo VB, Antunes HK, Gimenez PR, Santiago ML, Tufik S, Mello MT. Negative addiction to exercise: are there differences between genders? Clinics. 2011;66:255-60.

\section{Correspondence:}

Leonardo de Sousa Fortes

Rua Francisco da Cunha, 1340/1001, Boa Viagem

51020041 - Recife, PE - Brazil

Tel./Fax: +55 (81) 3204.8979/8114.4085

E-mail: leodesousafortes@hotmail.com 